\title{
炭素/窒化ホウ素固体潤滑超格子膜の 形成とそのトライボロジー特性*
}

関 根 幸 男*1, 三宅 正二郎*2, 渡 部 修一*3

\section{Deposition and Tribology of Carbon and Boron Nitride Superlattice Solid Lubricating Films}

\author{
Yukio SEKINE*4, Shojiro MIYAKE and Shuichi WATANABE \\ ${ }^{* 4}$ Graduate School of System Engineering, Nippon Institute of Technology, \\ 4-1 Gakuendai, Miyashiro-machi, Saitama, 345-8501 Japan
}

\begin{abstract}
Carbon and boron nitride superlattice films were deposited by RF sputtering using two semicircular targets. Superlattice $(\mathrm{C} / \mathrm{BN}) \mathrm{n}$ films were deposited by controlling the opposing time of the substrate to each of the graphite and boron nitride semicircular targets. Micro-Vickers hardness, nanoindentation hardness and nanoscratching properties of these films were evaluated. Both microVickers and nanoindentation hardnesses of the $4 \mathrm{~nm}$-period $(\mathrm{C} / \mathrm{BN}) \mathrm{n}$ multilayered film are the highest of all $(\mathrm{C} / \mathrm{BN})_{\mathrm{n}}$ films. Multilayered film of a suitable period has superior hardness and nanoscratching resistance. From the nanoscratching test evaluation, oscillatory scratching test, and ball-on-disk tribo test, the friction of the $4 \mathrm{~nm}$-period $(\mathrm{C} / \mathrm{BN}) \mathrm{n}$ multilayered film is lower than those of other $(\mathrm{C} / \mathrm{BN}) \mathrm{n}$, carbon, boron nitride and carbon nitride films. The $4 \mathrm{~nm}$-period $(\mathrm{C} / \mathrm{BN}) \mathrm{n}$ multilayered films show the least damage and superior sliding endurance.
\end{abstract}

Key Words: Solid Lubrication, Superlattice Films, Hardness, Tribology, Wear, Friction .

\section{1. 緒言}

トライボロジー用途の薄膜として,而摩耗特性を向上させ るためホウ素, 炭素, 窒素を構成要素とする超硬質膜が注目 されている(1)-(3). また, 表面の潤滑特性を改善させるため, 摩擦係数を下げる固体潤滑薄膜の適用も期待されている(1). (4). この固体潤滑膜は, 機器の動作環境に潤滑油では適応できな い過酷な環境(高温·真空環境等)が存在するために, 潤滑油 に代わり適用する場合が増加している(4),(5).これら固体潤 滑剂としては, $\mathrm{Au}$ (金)，Ag(銀)のような軟質金属材料と $\mathrm{MoS}_{2}$ (二硫化モリブデン), WS $($ (二硫化タングステン)などの層状 結晶の無機化合物およひPTFE(ポリテトラフルオロエチレ ン)などの高分子材料が代表的なものである(1).(4).(5).

一方, 超硬質膜として薄膜を数nm単位で積層させた超格 子膜が検討されており，CNx/TiN(6), TiN/AlN(7)などの積層 薄膜の研究が行われている.これに対して著者らは,新しい

*原稿受付 2001 年 5 月 23 日.

*1 正員, 日本工業大学大学院(函345-8501 埼玉県南埼玉郡宮 代町学園台 4-1).

*2 正員, 日本工粱大学工学部.

*3 日本工業大学工学部.

E-mail : s979016@stu.nit.ac.jp
超格子膜の形成を目的とし，CN(窒化炭素)膜およひBN (窒化 ホウ素)膜を数nm単位で積層させた $(\mathrm{C} V / \mathrm{BN}) \mathrm{n}$ 積層膜の研究 を行った ${ }^{(8)}$.その結果, 数nm周期の (CN/BN) n積層膜の形成 が確認され,硬さおよびマイクロ摩耗特性は著しい積層周期 依存性を示し, 積層周期 $4 \mathrm{~nm}$ で硬さが最大值となり，超格子 膜特有の機械的特性変化が得られた ${ }^{(8) .(9)}$

更に,これらの超格子膜をトライボロジー分野へ応用する ため著者らは，積層方向の弹性率増加および滑り面のせん断 力が一定であることを利用して，従来よりも低摩擦となる固 体润滑膜を提案してきた(10).

本研究では，上記の硬質膜である超格子膜形成技術を利 用し, 薄膜の弾性率增大に伴い垂直方向の硬さを著しく增 大させ, 基板と平行となる滑り面のせん断抵抗を,ほぼ一 定に保つことによって，硬さ増加の効果により摩擦係数を 減少させることを考え, 従来の単体膜や混合膜材料では得 られなかった低摩擦を示す，新しい固体潤滑膜の形成を目 的とした。

具体的には,グラファイトおよびh-BN構造を有する,C(炭 素)膜とBN膜を取り上げ，数 $\mathrm{nm}$ 周期で積層化した超格子膜 を形成し、硬さおよひ摩擦特性を評価した結果を報告する。 


\section{2. 実験方法}

$2 \cdot 1$ 成膜方法 膜の形成には, 図1に示すターゲッ 卜ならびに基板ホルダ両方に高周波RF電力を印加できるRF スパッタ装置を用いた.そして,半円形状のグラファイド 窒化ホウ素焼結体をターゲットとし,ターゲットホルダに固 定して薄膜を基板上に形成した.積層膜形成の順序としては BN膜を最初に形成し, C膜が最上層となる $(\mathrm{C} / \mathrm{BN}) \mathrm{n}$ 膜を形成 した.積層周期は前報で最も硬い特性を示した $4 \mathrm{~nm}^{(8)}$ と,周 期4nmの1/2倍となる周期 $2 \mathrm{~nm}$, 2倍となる周期 $8 \mathrm{~nm}$ とした. また，比較対象としてC, BNの単体膜および同一バイアス条 件で形成した $(\mathrm{CN} / \mathrm{BN}) n$ 膜の積層周期 $4 \mathrm{~nm}^{(8)}$ 膜も取り上げた. ここで,試験片基板にはSiウェハを用いた。

基板を設置し, 前処理としてArスパッタクリーニングを 行った．その後，基板ホルダの回転制御により，図2に示す ようなC膜とBN膜を交互に層状に形成した.また, 単体膜 および積層膜全体の膜厚は, 約100〜130nmに設定した。

\section{$2 \cdot 2$ トライボロジー評価方法＼cjkstart膜の硬さをビッ} カース微小硬度計およびナノインデンテーション試験装置に て測定した.ビッカースでは, 押し付け渮重0.05N, 荷重保 持時間10sで測定した.また,ナノインデンテーションでは, 押し付け荷重 $100 \mu \mathrm{N}$ で測定した.その硬さは，ナノインデ ンテーション曲線から得られる除荷曲線の接線とX軸の交点 から弾性回復を補正した塑性变形染さを求め,さらに幾何学 的に塑性変形断面積 $A r$ を算出し，(1)式より硬さ $H$ を求めた. 尚, Pmaxは測定時の最大荷重である ${ }^{(8)}$.

$H=P \max / A r \cdots \cdots \cdot \cdots(1)$ そして, 薄膜自体のトライボロジ一特性を明らかにするた

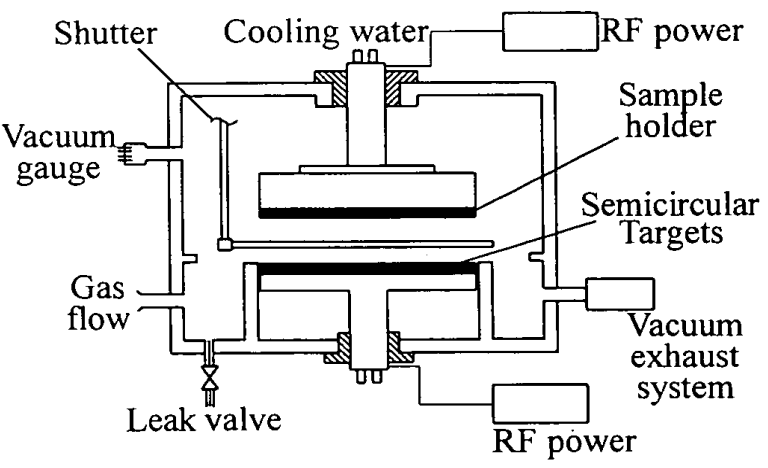

Fig.1 Schematic illustration of RF sputtering

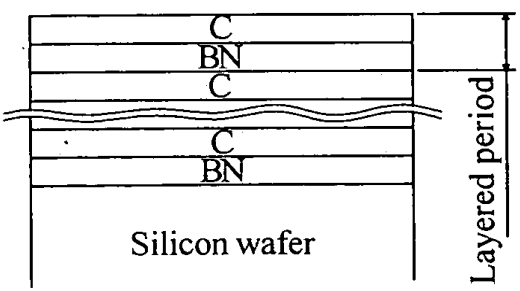

Fig.2 Superlattice solid lubricating films
め, AFM(原子間力顕微鏡)を用いたナノスクラッチ試験を 行った．その概略図を図3に示す．圧子にダイヤモンドチッ プを用いて, 負荷速度 $6.7 \mu \mathrm{N} / \mathrm{s}$, 最大荷重 $200 \mu \mathrm{N}$ の設定 条件にて, 荷重を順次増加させながらスクラッチ試験を行い 評価した。

さらに,膜の破壊特性および付着力に関する情報を得るた め, 摇動型のスクラッチ試験を行い,その際に発生するア コースティックエミッション $(\mathrm{AE})$ を評価した.

また,マクロな摩擦特性評価には，図4に示す油圧式の往 復型摩擦詿験装置およひ鹵5のボールオンディスク型の摩擦 試験装置を用いた，往復型試験装置では，相手圧子に $\operatorname{SUS} 440 C(\phi 6.0 \mathrm{~mm})$ を用いて, 荷重0.1 9.8Nの荷重領域と なる膜の荷重依存性を評価した.そして,ボールオンディス ク型の摩擦試験装置では, 相手圧子に $2 \mathrm{rO}_{2}(\phi 5.0 \mathrm{~mm})$ を用い て測定を行った。そその際, 摩擦試験条件は, 荷重 $9.8 \mathrm{~N}$, 回 転半径 $3 \mathrm{~mm}$, 摩擦速度 $94 \mathrm{~mm} / \mathrm{s}$ とした.ここで, 試験環境は 無潤滑である。

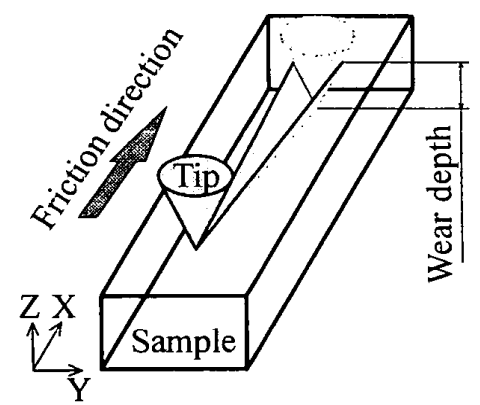

Fig.3 Schematic representation of a load gradual increase nanoscratching test

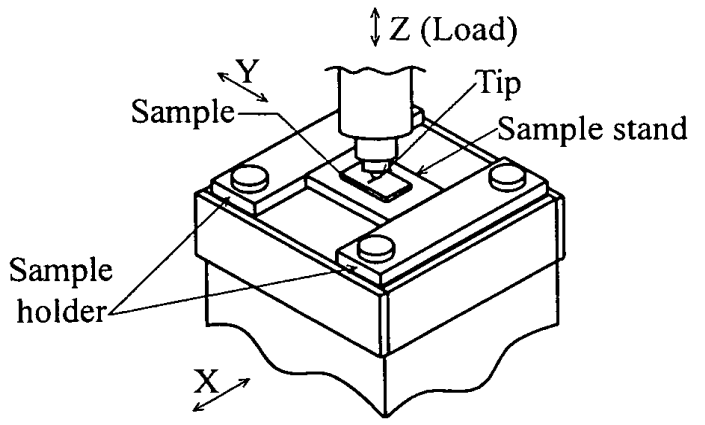

Fig.4 Reciprocating of friction tester

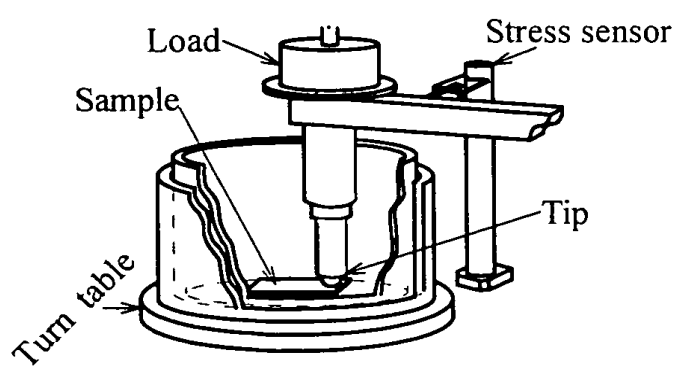

Fig.5 Ball-on-disk type friction tester 


\section{3. 実験結果および考察}

\section{$3 \cdot 1$ 硬さ}

$3 \cdot 1 \cdot 1$ マイクロビッカース硬さ 図 6 に薄膜 形成後の硬さを示す.BN単体膜は，圧痕部に基板との剥離が 発生しため測定が不可能であった. 固体潤滑効果を期待して 形成した (C/BN)n膜は, 積層周期により硬さが変化してお り, 周期4nmで硬さが増加する結果が得られたここれより, (CN/BN) n膜と同様に, 積層周期 $4 \mathrm{~nm}$ 付近が硬さの最大值で あると考えられる。

\section{$3 \cdot 1 \cdot 2$ ナノインデンテーション硬さ 薄膜形} 成後の圧子侵入深さと荷重との関倸を図7に, 図7の曲線よ り得られた硬さを図8に示す.ここでもBN膜は，圧子侵入 深さが極端に変動し,再現性が得られなかった。

ナノインデンテーション曲線より，C膜および周期 $2,8 \mathrm{~nm}$ の(C/BN)n n膜では, 最大圧子侵入深さが約 $15 \mathrm{~nm}$ 前後であり， $3 \mathrm{~nm}$ 程度の塑性変形が確認される. しかし, (C/BN) n膜の周期

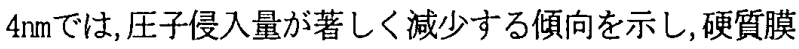
である $(\mathrm{CN} / \mathrm{BN}) n$ 膜に近い軌跡を示し, $(\mathrm{CN} / \mathrm{BN})$ n膜と同様に 弾性変形のみが生じている.

また,マイクロビッカースでは圧子が膜を突き抜けている ため，下地であるSi基板の影響があり，膜自体の硬さが得 られていないと考えられる.これに対して,ナノインデン テーションの圧子侵入深さは, 約3〜17nmであり,下地で ある基板の影響が少ないため,薄膜自体の硬さが得られたと 考えられる.そのため, 積層周期 $4 \mathrm{~nm}$ 付近が (C/BN)n膜の硬 さの最大値であることがより明確になっている.

3.2 ナノスクラッチ試験試験時の摩擦力および 摩擦係数の変動を図9に示す.摩擦力は, 変動の大きいBN膜 が最も高い值を示したここれは, 硬度が他の膜と比べ低いた め,破壊が初期段階から発生し，摩擦力が増大したと考えら れる.一方, (C/BN)n膜では周期依存性が確認され, 摩擦力低 減の効果は, 硬さ同様周期4nmが最も著しかった.

摩察系数の変動では，低荷重における初期の摩擦係数は高く 変動しているが, $40 \mu$ NN上上でほぼ安定した一定の值を示した.

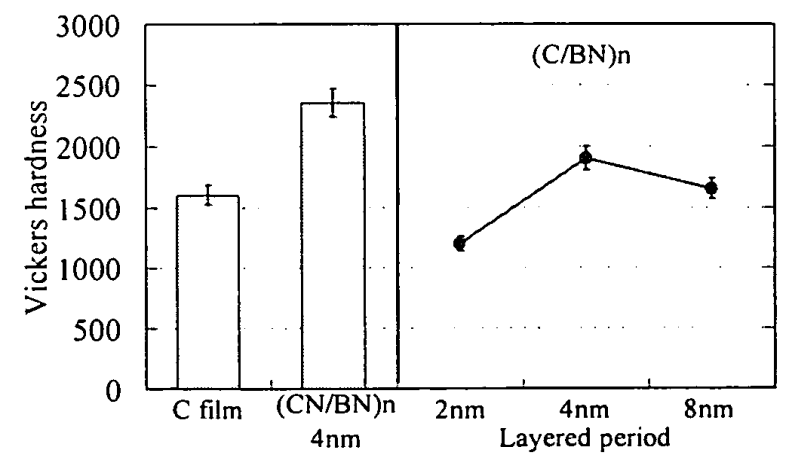

Fig.6 Vickers hardness of superlattice films

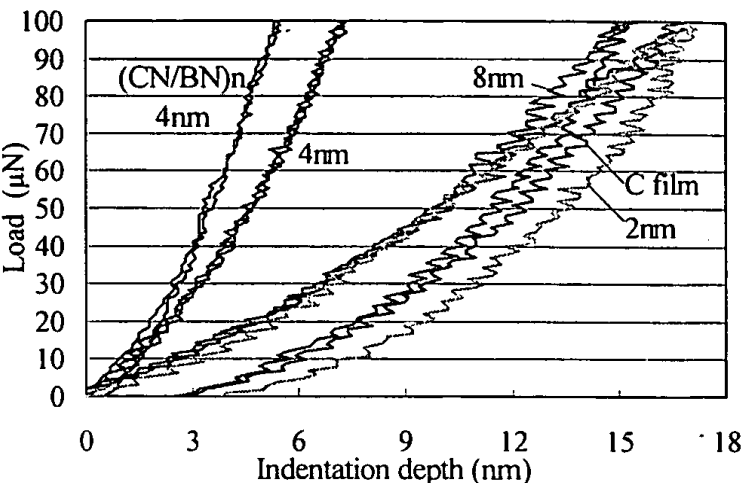

Fig.7 Nanoindentation curve of superlattice $(\mathrm{C} / \mathrm{BN}) \mathrm{n}$ films

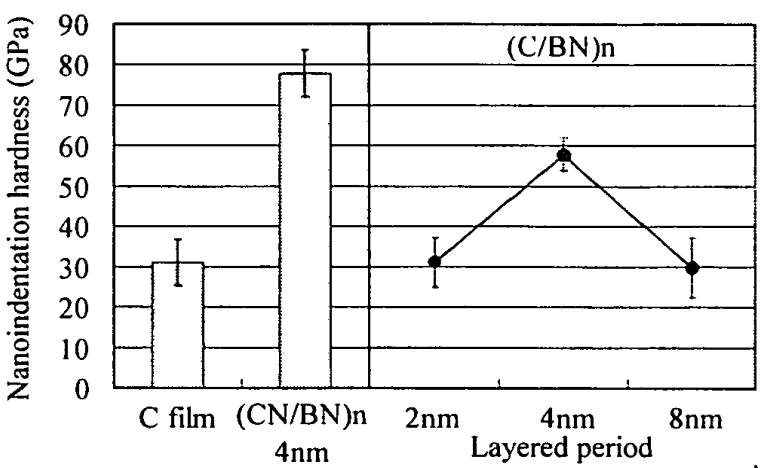

Fig.8 Nanoindentation hardness of superlattice films

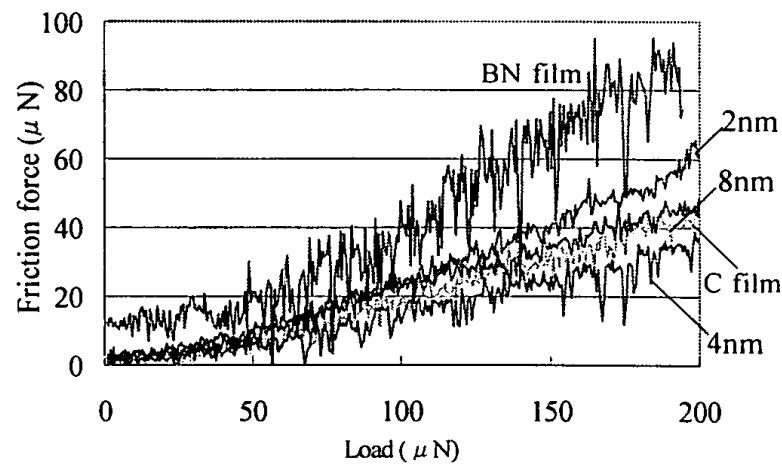

(a) Friction force

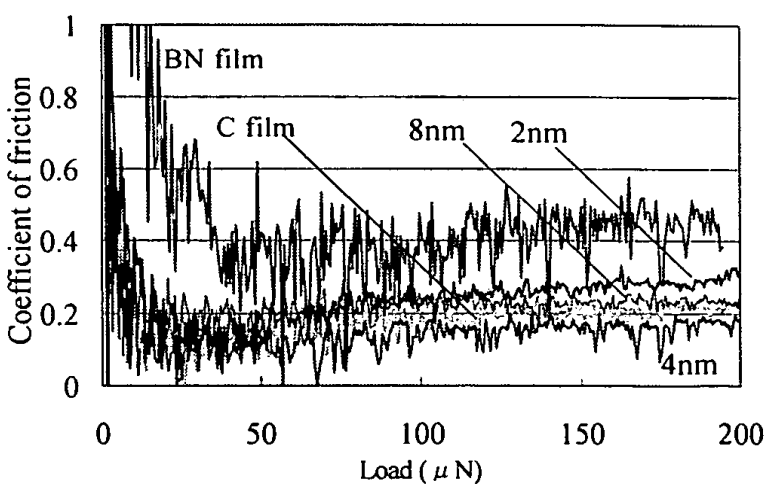

(b) Coefficient of friction

Fig.9 Friction of (C/BN)n films in a load gradual increase nanoscratching test

(Diamond tip, Load $0 \sim 200 \mu \mathrm{N}$, Frictional late $6.67 \mu \mathrm{N} / \mathrm{s}$ ) 
それぞれ安定後の摩擦係数值を見ると, BN膜の $\mu=0.45 に$ 対 し, (C/BN) n膜の周期 $2 \mathrm{~nm}$ では $\mu=0.28$, 周期 $8 \mathrm{~nm}$ では $\mu=$ 0.24 と減少する.また, C膜では $\mu=0.22$ に対し, $(\mathrm{C} / \mathrm{BN}) \mathrm{n}$ の周期 $4 \mathrm{~nm}$ では $\mu=0.17$ とさらに減少する傾向を示した.こ れは; スクラッチ面のせん断強度が，単体膜の固有特性值と それ程変化しないのに対し, 積層方向の弹性率増加により硬 さが周期4nmで増加しているため, (2)式よりせん断抵抗 $S$ が単体膜と同じとなり, 硬さ $H$ が増加するため (C/BN)n膜 の摩擦保数 $\mu$ が減少すると考えられる.

$$
\mu=s / H \ldots \ldots \ldots(2)
$$

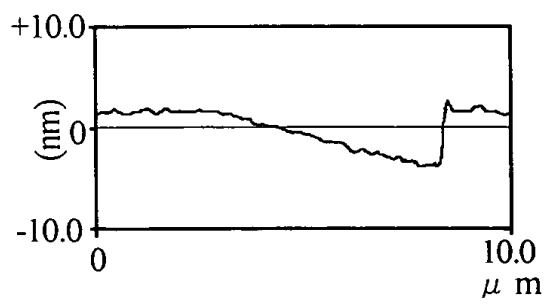

(a) C film

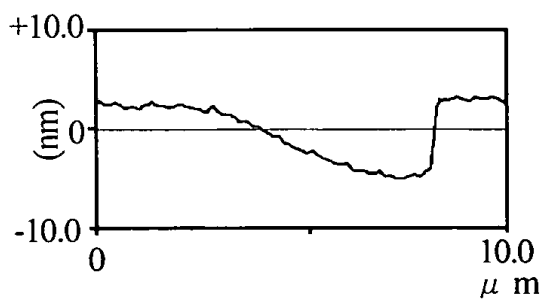

(b) $\mathrm{BN}$ film

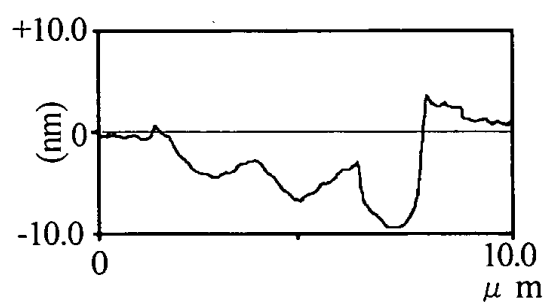

(c) Layered period $2 \mathrm{~nm}$

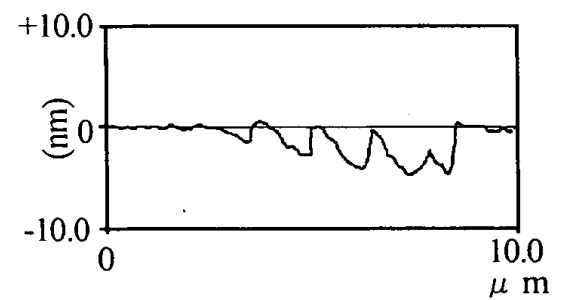

(d) Layered period $4 \mathrm{~nm}$

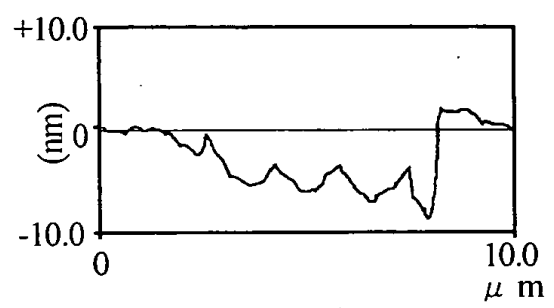

(e) Layered period $8 \mathrm{~nm}$

Fig.10 Wear marks obtained by a load gradual increase nanoscratching test
また,ナノスクラッチ試験後の摩耗痕形状例を図10に, 最 大摩耗樑さを図 11 に示すC, BN単体膜の摩耗痕は比較的滑ら かになっている.これに対し，積層膜の場合は，摩耗痕の凹 凸が大きくなっている.これは,スクラッチ時の荷重増加に 伴う破壊進展において, 単体膜では連続的に生じるが,超格 子膜では積層膜の境界部による抑止効果 ${ }^{(9)} か ゙$ 作用しているこ とが考えられる。

摩耗痕は, (C/BN) n膜の周期 $4 \mathrm{~nm}$ が最も小さく摩耗低減効 果が明らかである.しかも,最大深さも積層周期依存性を示 し,ナノインデンテーション硬さと対応する結果となった。 従って, 積層方向の弾性率増加により，圧子の侵入媣さが減 少していることが明らかである.

$3 \cdot 3$ 摇動型スクラッチ試験 。図 12 に, 摇動型ス クラッチ試験後の結果を示す.ここでスクラッチ波形の傾き は摩擦係数に対応する.その際得られたAEカウント数も同 一図面上に示した.

スクラッチ波形では, 比較的(C/BN) n 膜の周期 $4 \mathrm{~nm}$ の傾き が低くなり,ナノスクラッチ試験で摩擦係数が最も低くなっ た結果と対応する.また, AEカウント数自体も少なく, $\mathrm{AE}$ が急増する荷重が一番大きくなった.これは, 試料表層部の 破壊が生じにくいためと考えられ，単体膜や他の周期の膜よ りも, 耐荷重性能および付着力に優れていることが明らか となった.

3.4 往復型犘擦試験 図13に各種薄膜の摩摖特 性の荷重依存性を示す, BN単体膜および(CN/BN)n膜では, 摩擦係数の変動が大きく比較的高い值を示すのに対して,C 膜および(C/BN)n膜の周期 $4 \mathrm{~nm}$ では摩擦係数が減少して $\mu=$ 0.25 前後の值を維持している.特に高荷重領域においては, 摩擦倸数が更に减少している.また, BN単体膜, $(\mathrm{CN} / \mathrm{BN}) n$ 膜 および(C/BN)n膜の周期2,8nmでは，損傷が著しく低荷重 領域でも膜の剥離が観測された。これに対して,C単体膜お よび周期 $4 \mathrm{~nm}$ では,摩擦面の損傷はほとんど観測されなかっ た. しかし，C膜と (C/BN) n 膜の周期 $4 \mathrm{~nm}$ との比較では, 荷 重1ONにおいてC単体膜のみ損傷が観測された。

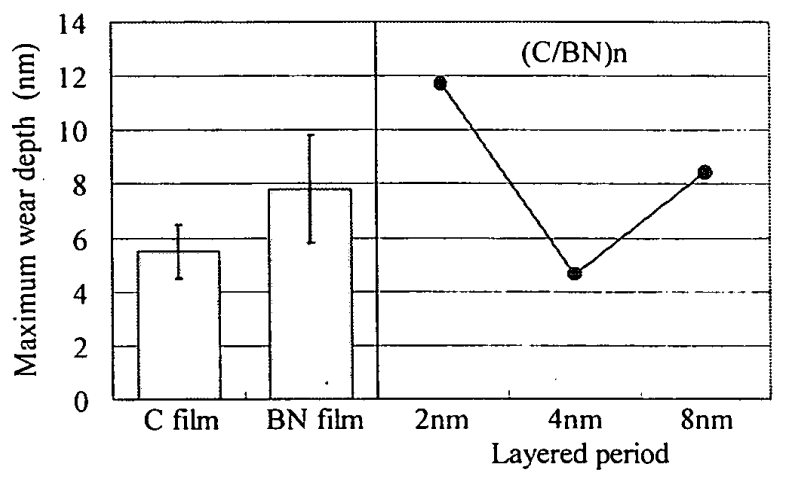

Fig.11 Maximum wear depth by a load gradual increase nanoscratching test 


\section{$3 \cdot 5$ ボールオンティスク型摩揊試験}

\section{5 .1 摩擦回数依存性図14k, 荷重9.8Nで行っ} た摩擦係数の摩擦回数依存性を示す.また, 摩摖回数 1000 回転後の各種試験片の摩擦面を図15に示す. (C/BN)n膜の周 期 $4,8 \mathrm{~nm}$ 以外では, 初期段階から摩擦係数が高く $\mu=0.3$ 以上となり， $\mu=0$. 4付近からは下地のSi基板が観測された.

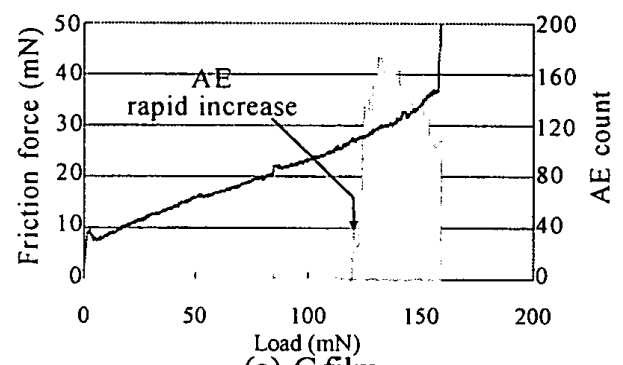

(a) C film

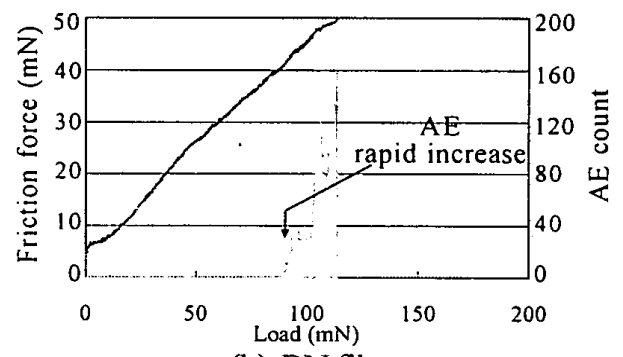

(b) $\mathrm{BN}$ film

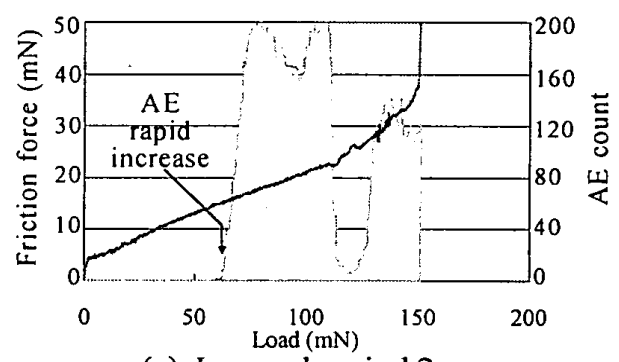

(c) Layered period $2 \mathrm{~nm}$

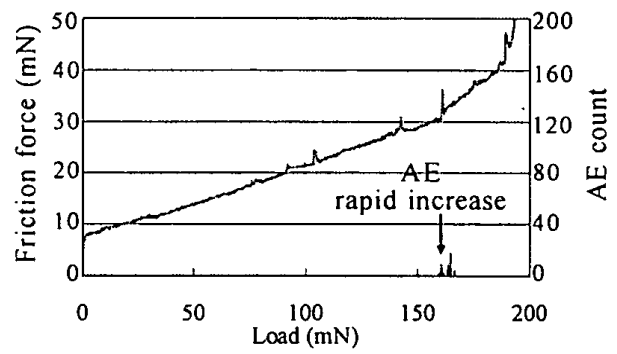

(d) Layered period $4 \mathrm{~nm}$

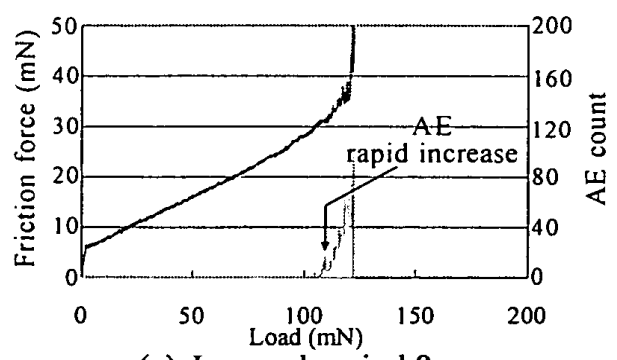

(e) Layered period $8 \mathrm{~nm}$

Fig. 12 Results of scratching test
これに対し, 皘層周期 $4,8 \mathrm{~nm}$ の (C/BN)n膜では, 1000 回転 まで比較的低い值を示しており，周期 $8 \mathrm{~nm}$ は $\mu=0.25$ 付近 を，周期 $4 \mathrm{~nm}$ では $\mu=0.15$ 付近の值を維持している.

また，摩擦面の損傷では、ほとんどの試験片が下地のSi 基板が観測される程損傷しているのに対して, (C/BN)n膜の 周期4,8nmでは下地のSi基板は観測されなかった. 更に, 周 期 $4 \mathrm{~nm}$ と $8 \mathrm{~nm}$ を拡大して比較すると，図15示す様に周期 $8 \mathrm{~nm}$ の摩耗痕が観測されるが,周期4nmでは摩耗痕が観察されな い. 従って, 積層周期 $4 \mathrm{~nm}$ で, 摩擦係数同様に最も耐摩耗性 が改善されている。

$3 \cdot 5 \cdot 2$ 膜匽依存性 今まで評価した薄膜は, 膜厚 が約100nmと薄い条件で評価した，そのため，低摩擦の值を 示しているが，摩擦に対する寿命が短いと思われる.そこで， 最も特性が優れている $(\mathrm{C} / \mathrm{BN}) \mathrm{n}$ 膜の周期 $4 \mathrm{~nm}$ を取り上げ，膜 厚を2倍の約 $200 \mathrm{~nm}$ として形成し，その摩擦回数依存性を評 価した.測定条件は前項と同一で行い,その結果を図16に 示す.この結果より, 膜厚 $100 \mathrm{~nm}$ では, 摩擦回数 2500 回付 近で膜に破壊が生じて $\mu=0.4$ 以上となった.これに対し て, 膜厚 $200 \mathrm{~nm}$ では, 摩擦回数 5800 回付近まで摩擦係数は 低かった.C, BN単体膜や他の積層周期の膜が, 表面に損傷 を生じて摩擦係数が増大していることを考えると,4nm周期 の(C/BN)n膜は優れた固体潤滑特性を示寸ことが明かである.

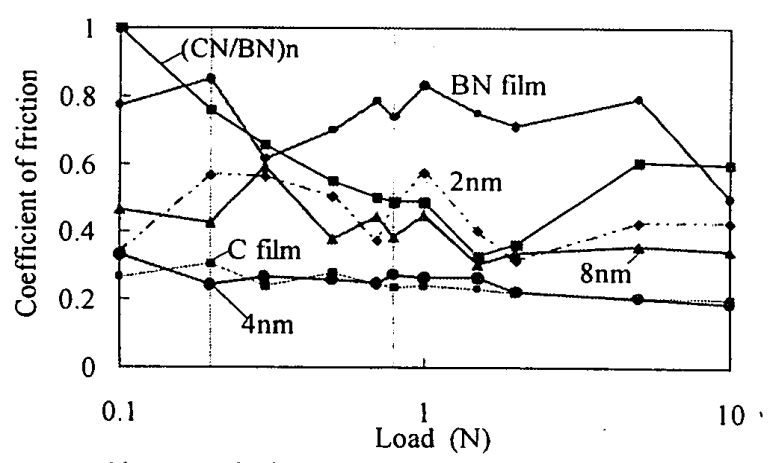

Fig.13 Friction dependencies on load by reciprocating friction tester

(Sliding distance $10 \mathrm{~mm}$, Cycle 50)

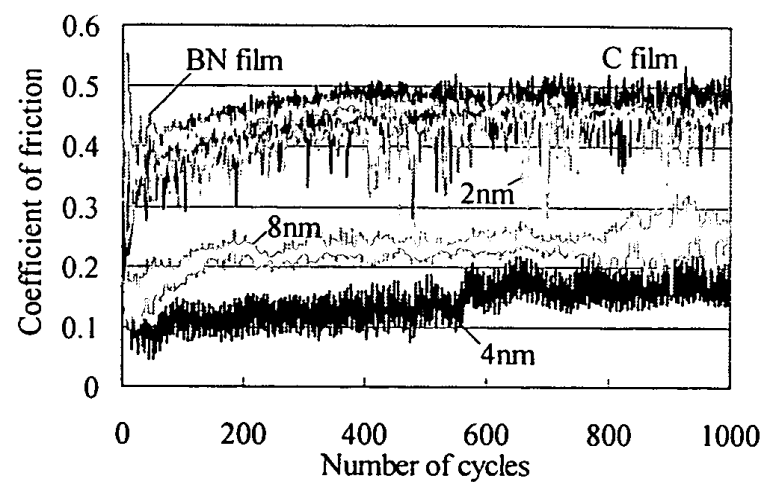

Fig. 14 Friction dependencies on number of cycles by ball-on-disk friction tester (Load $9.8 \mathrm{~N}$, Sliding velocity $94 \mathrm{~mm} / \mathrm{s}$ ) 


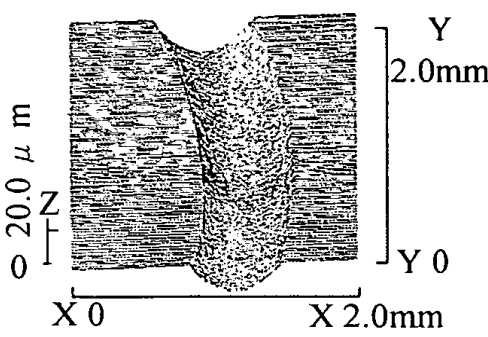

(a) $\mathrm{C}$ film

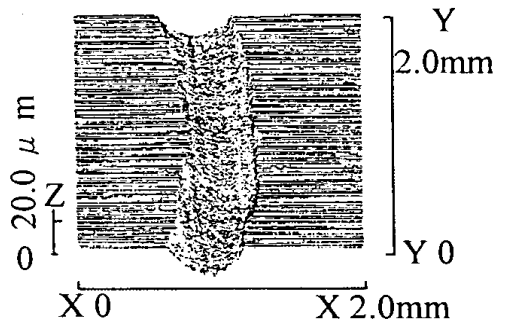

(b) BN film

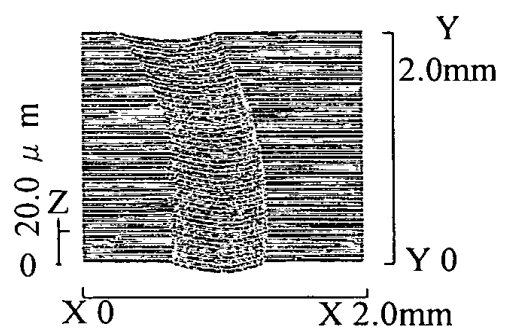

(c) Layered period $2 \mathrm{~nm}$

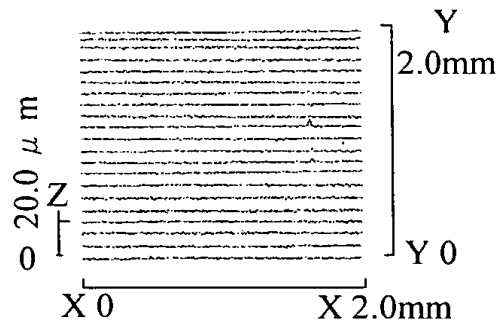

(d) Layered period $4 \mathrm{~nm}$ (Enlarged)

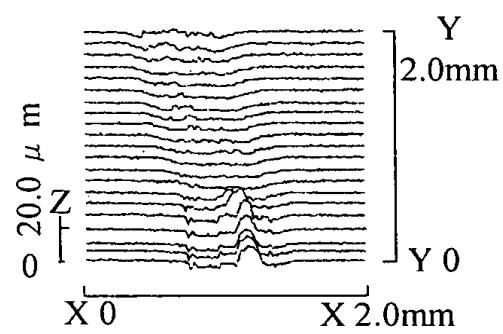

(e) Layered period $8 \mathrm{~nm}$ (Enlarged)

Fig.15 Surface morphology of wear by ball-on-disk friction tester

\section{4. まとめ}

グラファイトおよびh-BN構造など固体潤滑特性が期待 できる,C膜とBN膜を取り上げ, 数nm周期で積層化し， 硬さや摩擦特性の評価を行い次の結果を得た。

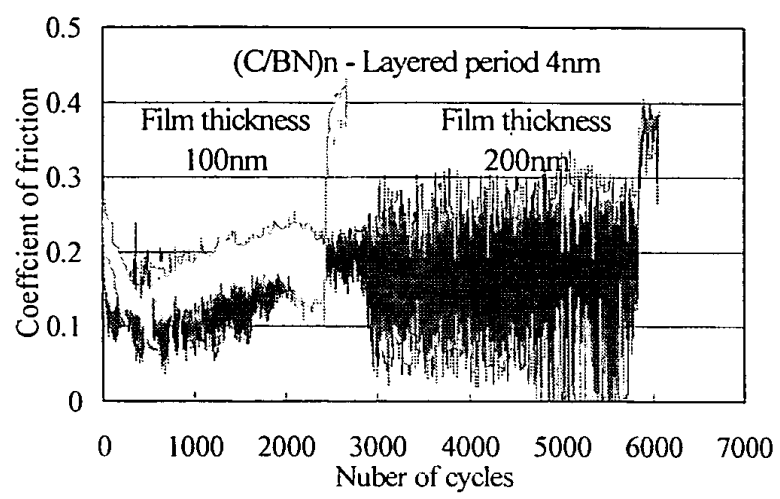

Fig.16 Friction dependencies on film thickness by ball-on-disk friction tester (Load $9.8 \mathrm{~N}$, Sliding velocity $94 \mathrm{~mm} / \mathrm{s}$ )

（1） マイクロビッカースおよびナノインデンテーション硬 さで(C/BN) n膜は, 積層周期依存性を示し, 周期 $4 \mathrm{~nm}$ で最大 の值を示した.

（2）ナノスクラッチ試験では, (C/BN) n膜の周期 $4 \mathrm{~nm}$ が最も 低摩擦を示した.これは，積層方向の弾性率増加に対して， 滑り面のせん断抵抗の変化が (C/BN) n膜の周期4nmは小さ く,その結果として摩擦係数が減少していると考えれられる.

（3）往復およびボールオンディスク型の摩擦試験において (C/BN)n膜の周期 $4 \mathrm{~nm}$ は, 摩擦倸数および摩擦面の損傷に著 しい特性改善効果が得られた。

\section{謝辞}

本研究の実験に協力して頂いた, 日本工業大学の田島義明 君, 本告健君, 高橋宏幸君に感謝する。また, 本研究の一部 は,科学技術振興調整費「極限環境のマイクロトライボロ ジー」により助成された。

\section{文献}

（1）榎本·三宅薄莫トライボロジー，東京大学出版会（1994）.

（2）三宅正二郎, 機械学会学会誌, 102, 962（1999）15.

(3) Miyake, S. , ほか5名, Appl. Phys. Lett. 65， 25 (1994) 3206.

（4） 日本潤滑学会, 潤滑ハンドブック,養賢堂(1987).

（5）日本潤滑学会, 新材料のトライボロジー, 養賢堂(1991).

(6) Li, D. ほ ほか6名, Appl. Phys. Lett. 67 (1995) 203.

（7）中山明，日本機械学会学会誌，100, 943 (1997) 593.

（8）三宅·関根·渡部，日本機械学会論文集，65，639 C編 (1999) 4496.

（9）三宅，ほか3名,精密工学会誌, 66, 12 （2000)，1958.

（10）平野.三宅，特許 1930397 号，特公平6-62975(1994). 